\title{
KETERGANTUNGAN MAHASISWA TERHADAP ROKOK
}

\author{
Hadinoto, Eni Suhesti, Muhammad Ikhwan \\ Staf Pengajar Fakultas Kehutanan Universitas Lancang Kuning \\ JIn. Yos Sudarso Km. 8 Rumbai Pekanbaru Riau Telp./Fax. (0761) 54092 \\ Email :hdinto@yahoo.co.id\&hesti1170@yahoo.co.id\&mmighwan@yahoo.com
}

\begin{abstract}
One of the sources of air pollutants are carried by most humans is cigarette smoke. Effects of smoking are numerous and dangerous to the health of both active smokers (actors) as well as passive smokers. The habit of smoking by the community of long standing. Smokers are generally carried out by people who are reaching adulthood from various circles, one of which is the student. Cigarette smoke is a pollutant for humans and the surrounding environment. Many diseases have been shown to arise from smoking, either directly or indirectly. This study aimed to: identify the level of dependence of Lancang Kuning University students Pekanbaru to smoking. This research was conducted at the campus of the University of Lancang Kuning. Data were obtained from filling the questionnaire will be processed in the following way Fargerstorm Tolerance Questionnaire Br J Addict. The number of respondents as many as 30 students obtained the degree of dependence on cigarettes ranging from mild, moderate and height / weight. Several factors are thought to affect, among other things such as limited money (still depending on shipment parent), time to smoke limited (for lectures and practicum) and there is an effort to save money. In this study, the students obtained the degree of dependence on cigarettes: lightweight (6.67\%), moderate (70\%) and high (23.33\%).
\end{abstract}

Keywords: dependence, cigarettes, college students

\section{PENDAHULUAN}

\section{Latar Belakang}

Perwujudan kualitas lingkungan yang sehat merupakan bagian pokok di bidang kesehatan. Udara sebagai komponen lingkungan yang penting dalam kehidupan perlu dipelihara dan ditingkatkan kualitasnya sehingga dapat memberikan daya dukungan bagi mahluk hidup untuk hidup secara optimal. Pencemaran udara dewasa ini semakin menampakkan kondisi yang sangat memprihatinkan. Sumber pencemaran udara dapat berasal dari berbagai kegiatan antara lain industri, transportasi, perkantoran, dan perumahan. Berbagai kegiatan tersebut merupakan kontribusi terbesar dari 
pencemar udara yang dibuang ke udara bebas. Sumber pencemaran udara juga dapat disebabkan oleh berbagai kegiatan alam, seperti kebakaran hutan, gunung meletus, gas alam beracun, dll. Dampak dari pencemaran udara tersebut adalah menyebabkan penurunan kualitas udara, yang berdampak negatif terhadap kesehatan manusia.

Udara merupakan media lingkungan yang merupakan kebutuhan dasar manusia perlu mendapatkan perhatian yang serius, hal ini pula menjadi kebijakan Pembangunan Kesehatan Indonesia 2010 dimana program pengendalian pencemaran udara merupakan salah satu dari sepuluh program unggulan. Diperkirakan pencemaran udara dan kebisingan akibat kegiatan industri dan kendaraan bermotor akan meningkat 2 kali pada tahun 2000 dari kondisi tahun 1990 dan 10 kali pada tahun 2020.

Sumber pencemaran udara dapat pula berasal dari aktifitas rumah tangga dari dapur yang berupa asap, Menurut beberapa penelitian pencemaran udara yang bersumber dari dapur telah memberikan kontribusi yang besar terhadap penyakit ISPA. Penderita ISPA pada daerah bencana asap meningkat sebesar 1,8-3,8 kali lebih besar dari jumlah penderita ISPA pada periode yang sama tahun-tahun sebelumnya. Salah satu sumber pencemar udara yang dilakukan oleh sebagian manusia adalah asap rokok. Dampak rokok sangat banyak dan berbahaya bagi kesehatan baik bagi perokok aktif (pelaku) maupun perokok pasif.

Kebiasaan merokok oleh masyarakat sudah berlangsung lama. Perokok pada umumnya dilakukan oleh orang yang sudah menginjak uisa dewasa dari berbagai kalangan, salah satunya adalah mahasiswa. Berdasarkan hasil wawancara penulis dengan beberapa anggota masyarakat bahwa merokok sudah menjadi kebiasaan sehari-hari. Penyebab utama antara lain rasa ketergantungan terhadap rokok. Kondisi demikian tentu saja merugikan mahasiswa sendiri dan orang lain. Oleh karena itu diperlukan langkah-langkah penanganan oleh pihak-pihak yang terkait. Untuk itu diperlukan beberapa kajian, di antaranya adalah mengetahui tingkat ketergantungan mahasiswa dalam mengkonsumsi rokok. Dalam penelitian ini kajian dilakukan pada mahasiswa Universitas Lancang Kuning Pekanbaru 


\section{Tujuan Penelitian}

Penelitian ini bertujuan untuk : mengidentifikasi tingkat ketergantungan mahasiswa Universitas Lancang Kuning Pekanbaru terhadap rokok

\section{Manfaat Penelitian}

Hasil penelitian ini diharapkan merupakan data awal dalam penyadaran terhadap masyarakat tentang bahaya merokok bagi kesehatan manusia dan lingkungan

\section{METODE PENELITIAN}

Penelitian ini dilakukan di Kampus Universitas Lancang Kuning.

\section{Pengumpulan data}

Data yang dikumpulkan dalam penelitian ini adalah data primer dan data sekunder :

\section{a. Pengumpulan Data Sekunder}

Pengumpulan data dilakukan dengan penelusuran pustaka atau data yang ada di lembaga/institusi terkait. Data sekunder dikumpulkan dari berbagai sumber yang relevan. b. Pengumpulan Data Primer

Data primer diperoleh melalui kegiatan survey dan observasi terhadap objek penelitian. Data yang diambil berupa kebiasaan mahasiswa dalam merokok.

\section{Metode Pengumpulan}

Data primer dikumpulkan melalui wawancara dengan responden menggunakan bantuan quisioner (terlampir). Penentuan responden dilakukan secara sengaja (purposive sampling) dengan kriteria tertentu, yaitu responden yang diwawancarai adalah mahasiswa yang merokok. Jumlah responden untuk setiap fakultas minimal 3 mahasiswa.

\section{Ananlisis Data}

Data yang diperoleh dari hasil pengisian kuisioner akan diolah dengan cara sebagai berikut (Fargerstorm Tolerance Questionnaire $\mathrm{Br} J$ Addict 1991); Cara menganalisis data hasil kuisioner seperti pada Tabel 1.

Tabel 1. Cara menentukan skor berdasar pada jawaban responden

\begin{tabular}{ccccc}
\hline \multirow{2}{*}{ No.Pertanyaan } & \multicolumn{5}{c}{ Skor Jawaban } \\
\cline { 2 - 5 } & A & B & C & D \\
\hline 1 & 0 & 1 & 2 & 3 \\
\hline 2 & 3 & 2 & 1 & 0 \\
\hline 3 & 1 & 0 & & \\
\hline 4 & 1 & 0 & & \\
\hline 5 & 1 & 0 & & \\
\hline
\end{tabular}




\begin{tabular}{ccccc}
\hline \multirow{2}{*}{ No.Pertanyaan } & \multicolumn{4}{c}{ Skor Jawaban } \\
\cline { 2 - 5 } & A & B & C & D \\
\hline 6 & 1 & 0 & & \\
\hline
\end{tabular}

Untuk menentukan tingkat ketergantungan terhadap rokok adalah : Ringan = skor $0-3$; Sedang = skor $4-6$ dan Tinggi $=$ skor $7-10$

Data yang diperoleh dianalisis secara deskriptif, yaitu penggambaran data yang diperoleh secara apa adanya, tanpa ada peng-generalisasian (Irianto 2007). Data akan digambarkan melalui tabel atau grafik.

\section{HASIL DAN PEMBAHASAN}

Jumlah batang rokok yang dihisap setiap hari
Jumlah batang rokok yang dihisap oleh setiap mahasiswa berbeda-beda setiap harinya. Beberapa mahasiswa ada yang menghisap kurang dari 10 batanag sehari tetapi terdapat juga yang menghisap rokok lebih dari 30 batang setiap hari. Rincian jumlah batang rokok yang dihisap oleh mahasiswa Universitas Lancang Kuning seperti pada Tabel 2.

Tabel 2. Jumlah batang rokok yang dihisap setiap hari

\begin{tabular}{ccc}
\hline No & Jumlah rokok (batang) & $\%$ \\
\hline 1 & $<10$ & 26.67 \\
\hline 2 & $10-20$ & 40.00 \\
\hline 3 & $21-30$ & 23.33 \\
\hline 4 & $>30$ & 10.00 \\
\hline & Jumlah & $\mathbf{1 0 0 . 0 0}$
\end{tabular}

Berdasar pada Tabel 2 di atas terlihat bahwa sebagian besar (40\%) mahasiswa menghisap rokok 1 bugkus per hari dengan asumsi sebungkus rokok berisi 12 - 16 batang. Dan mahasiswa yang menghisap 2 bungkus atau lebih hanya $10 \%$. Hal tersebut diduga mahasiswa masih membatasi kegiatan merokoknya karena beberapa faktor seperti keterbatasan uang (masih tergantung dari kiriman orang tua), waktu luang untuk merokok terbatas (untuk kuliah dan praktikum) dan ada upaya penghematan uang.

\section{Lama waktu menghisap rokok setelah bangun tidur \\ Lama waktu yang diperlukan mahasiswa untuk menghisap rokok}


setelah bangun tidur berbeda-beda menit setiap hari. Rincian lama waktu setiap harinya. Beberapa mahasiswa menghisap rokok oleh mahasiswa ada yang menghisap kurang dari 5 menit setelah banguna tidur tetapi terdapat Universitas Lancang Kuning setelah juga yang menghisap rokok setelah 60 bangun tidur seperti pada Tabel 3 .

Tabel 3. Lama waktu menghisap rokok setelah bangun tidur

\begin{tabular}{ccc}
\hline No & Lama waktu (menit) & $\%$ \\
\hline 1 & $<5$ & 26.67 \\
\hline 2 & $6-30$ & 53.33 \\
\hline 3 & $31-60$ & 16.67 \\
\hline 4 & $>60$ & 3.33 \\
\hline Jumlah & & $\mathbf{1 0 0 . 0 0}$ \\
\hline
\end{tabular}

Berdasar pada Tabel 3 di atas terlihat bahwa sebagian besar (53\%) mahasiswa menghisap rokok setelah 15 menit setelah bangun tidur. Dan mahasiswa yang menghisap rokok setelah 1 jam bangun hanya $3 \% \mathrm{Hal}$ tersebut diduga mahasiswa masih membatasi kegiatan merokoknya karena beberapa faktor seperti keterbatasan uang (masih tergantung dari kiriman orang tua), ketika waktu terbangun tidak langsung merokok tetapi mengerjakan kegiatan lain dan ada upaya penghematan uang.

\section{Menahan diri untuk tidak merokok di area terlarang}

Kebiasan untuk dapat menahan diri tidak merokok di tempat-tempat yang dilarang bagi sebagian mahasiswa dapat melakukan dan sebagian mahasiswa cukup berat. Beberapa mahasiswa ada yang dapat menahan diri untuk tidak merokok di tempat-tempat yang dilarang tetapi terdapat juga yang tidak bisa menahannya. Rincian kebiasan menahan diri untuk tidak merokok di area terlarang oleh mahasiswa Universitas Lancang Kuning setelah bangun tidur seperti pada Tabel 4.

Tabel 4. Menahan diri untuk tidak merokok di area terlarang

\begin{tabular}{ccc}
\hline No & Kemampuan menahan diri & $\%$ \\
\hline 1 & Ya & 43.33 \\
\hline 2 & Tidak & 56.67 \\
\hline Jumlah & & $\mathbf{1 0 0 . 0 0}$ \\
\hline
\end{tabular}


Berdasar pada Tabel 4 di atas terlihat bahwa sebagian besar (57\%) tidak mengalami kesulitan menahan diri untuk tidak merokok di area yang dilarang. Dan mahasiswa yang tidak bisa menahan diri sebanyak 43\% $\mathrm{Hal}$ tersebut diduga mahasiswa masih memiliki kepedulian terhadap aturan yang dibuat oleh pihak yang berwenang..

Frekuensi merokok pada jam pertama setelah bangun tidur
Kebiasaan merokok pada jam pertama setelah bangun tidur bagi setiap mahasiswa berbeda-beda. Sebagian mahasiswa ada yang sering merokok pada jam pertama setelah bangun tidur tetapi terdapat juga yang merokok pada waktu yang lain. Rincian kebiasan merokok pada jam pertama setelah bangun tidur oleh mahasiswa Universitas Lancang Kuning setelah bangun tidur seperti pada Tabel 5.

Tabel 5. Frekuensi merokok pada jam pertama setelah bangun tidur

\begin{tabular}{lcc} 
No & Frekuensi & $\%$ \\
\hline 1 & Ya & 50 \\
\hline 2 & Tidak & 50 \\
\hline Jumlah & & $\mathbf{1 0 0 . 0 0}$
\end{tabular}

Berdasar pada Tabel 5 di atas terlihat bahwa sebanyak 50\% mahasiswa merokok pada jam pertama setelah bangun tidur. Dan 50\% mahasiswa merokok diwaktu lain. Hal tersebut diduga mahasiswa masih memiliki kegiatan lain selain merokok.

Waktu yang sulit untuk menahan dan menghilangkan keinginan merorkok
Waktu keinginan merokok yang sulit ditahan dan dihilangkan oleh mahasiswa berbeda-beda. Sebagian mahasiwa dapat menahan diri dan menghilangkan keinginan merokok pada waktu lain dan tidak harus pada batang pertama di pagi hari. . Rincian waktu keinginan merokok yang sulit ditahan dan dihilangkan oleh mahasiswa Universitas Lancang Kuning setelah bangun tidur seperti pada Tabel 6 
Tabel 6. Waktu yang sulit untuk menahan dan menghilangkan keinginan merorkok

\begin{tabular}{ccc}
\hline No & Waktu & $\%$ \\
\hline 1 & Batang pertama di pagi hari & 40 \\
\hline 2 & Waktu lain & 60 \\
\hline & Jumlah & $\mathbf{1 0 0 . 0 0}$ \\
\hline
\end{tabular}

Berdasar pada Tabel 6 di atas

Kebiasaan merokok saat sakit

terlihat bahwa sebanyak $60 \%$

Kebiasan tetap merokok mahasiswa dapat menahan diri dan meskipun dalam keadaan sakit dilakukan menghilangkan merokok pada waktu oleh sebagian mahasiswa, meskipun lain. Dan 40\% mahasiswa sulit terdapat juga mahasiswa yang dapat menahan diri dan menghilangkan menahannya. Rincian kebiasan merokok kebiasan merokok diwaktu lain. Hal pada keadaan sakit oleh mahasiswa tersebut diduga mahasiswa masih memiliki kegiatan lain selain merokok.

Universitas Lancang Kuning setelah bangun tidur seperti pada Tabel 7 .

Tabel 7. Kebiasaan merokok saat sakit

\begin{tabular}{ccc}
\hline No & Kebiasaan merokok & $\%$ \\
\hline 1 & Ya & 76.67 \\
\hline 2 & Tidak & 23.33 \\
\hline Jumlah & & $\mathbf{1 0 0 . 0 0}$ \\
\hline
\end{tabular}

Berdasar pada Tabel 7 di atas terlihat bahwa sebanyak $77 \%$ mahasiswa tetap merokok meskipun dalam keadaan sakit. Dan hanya $23 \%$ mahasiswa yang dapat menahan ketika sedang sakit. Hal tersebut diduga mahasiswa sudah mulai timbul rasa ketergantungan terhadap rokok..
Tingkat ketergantungan terhadap rokok

Berdasar pada uraian di atas, dengan jumlah responden sebanyak 30 orang mahasiswa didapatkan tingkat ketergantungan terhadap rokok mulai dari ringan, sedang dan tinggi/berat. Tingkat ketergantungan mahasiswa terhadap rokok dapat dilihat pada Tabel 8. 
Tabel 8. Tingkat ketergantungan mahasiswa terhadap rokok

\begin{tabular}{ccc} 
No & Tingkat Ketergantungan & $\%$ \\
\hline 1 & Ringan & 6.67 \\
\hline 2 & Sedang & 70.00 \\
\hline 3 & Tinggi/berat & 23.33 \\
\hline Jumlah & & $\mathbf{1 0 0 . 0 0}$ \\
\hline
\end{tabular}

Dari Tabel 8 di atas bahwa sebanyak 70\% mahasiswa memiliki ketergantungan tingkat sedang terhadap rokok. Beberapa faktor yang diduga mempengaruhi hal tersebut antara lain seperti keterbatasan uang (masih tergantung dari kiriman orang tua), waktu luang untuk merokok terbatas (untuk kuliah dan praktikum) dan ada upaya penghematan uang

\section{KESIMPULAN DAN SARAN}

\section{Kesimpulan}

Berdasar pada hasil penelitian dapat disimpulkan sebagai berikut :
1. Tingkat

ketergantungan mahasiswa terhadap rokok untuk kategori “ringan' sebesar $6,67 \%$

2. Tingkat ketergantungan mahasiswa terhadap rokok untuk kategori "sedang' sebesar $70 \%$

3. Tingkat ketergantungan mahasiswa terhadap rokok untuk kategori 'tinggi/berat' sebesar $23,33 \%$

Saran

1. Perlu dilakukan penyuluhan tentang bahaya merokok oleh pihak universitas

2. Perlu dibuat aturan dan penerapanya tentang larangan merokok di kampus

\section{DAFTAR PUSTAKA}

Bayong . 1999. Etika Lingkungan. ITB Press. Bandung.

[WHO] World Health Organization. 1983. Laporan WHO tentang Perokok Kuncoro W. 2004. Bahaya Rokok 